\title{
Effect of biotic and abiotic factors on the population dynamics of wheat greenbug, Schizaphis graminum (Rondani) (Hemiptera: Aphididae) under Sohag governorate conditions.
}

\author{
Mohanny K. M. ${ }^{1}$, G. S. Mohamed ${ }^{1}$, A. W. Mahmoud ${ }^{2}$ and W. A. Abd El Baset ${ }^{3}$ \\ ${ }^{1}$ Department of Plant Protection, Faculty of Agriculture, South Valley University, Qena 8235, Egypt. \\ ${ }^{2}$ Agriculture Research Center, Plant Protection, Dokki, Giza, Egypt. \\ ${ }^{3}$ Agriculture Research Center, Agricultural Experiments Department, Qena, Egypt
}

\begin{abstract}
The present study was carried out in the Agriculture Experimental of Shandaweel Agriculture Research Station, Sohag Governorate during two successive seasons of 2015/2016 and 2016/2017. Results of both seasons showed the population fluctuation of S. graminum. The obtained results revealed that greenbug increased from $0.60,0.63$ nymphs/tiller on $3^{\text {rd }}, 4^{\text {th }}$ week of January respectively, to reach a peak of $82.80,66.40$ nymphs/tiller in $2^{\text {nd }}, 3^{\text {rd }}$ week of March respectively. Aptera of $S$. graminum started to appear in $4^{\text {th }}$ week of January and increased to reach a maximum of 11.00, 4.7 individuals/tiller on both seasons respectively. The peak of alatae reached 3.90, 4.70 individuals/tiller respectively, in the $4^{\text {th }}$ week of March. The population of all morphs started declining in the last week of March from field and disappeared by $1^{\text {st }}$ week of April. The grubs and adults of Coccinella septempunctata Linné appeared on the crop during the beginning of February and their population increased with the increase in aphid population. Its abundance was maximum on the $4^{\text {th }}$ week of March with average of 7.80, 9.06 individuals/tiller on both seasons respectively. The population of aphids had significant positive correlation with maximum, minimum, mean temperature were $0.6524,0.481,0.542$ in first season and $0.5687,0.472,0.364$ in the second season respectively. But it showed negative correlation with humidity in both seasons $-0.454,-0.391$ respectively. The studies evaluate in detail the abiotic and biotic factors regulating the wheat aphid populations.
\end{abstract}

Keywords: Wheat aphid, Schizaphis graminum (R), biotic and abiotic factors.

\section{Introduction}

Wheat (Triticum aestivum L.) is one of the most important and the most grown cereal crop. It is the staple food of many countries including Egypt. Its importance is derived from many properties and uses of its kernels, which make it a staple food for more than one-third of world 's population. Moreover,

*Corresponding author: Ghada S. Mohamed

Email: d.ghada1@yahoo.com

Tel.: +201000866728

Received: January 20, 2020;

Accepted: February 27, 2020;

Published: March 31, 2020. its straw is used as animal feed and in manufacturing paper (Milad et al., 2013). Various factors like late sowing, traditional method of seedbed preparation, poor quality seed imbalance use of fertilizer, water shortage and especially poor insect control were responsible for the low production of wheat (El-Gizawy, 2009). However, aphids and thrips were considered two of the important pests attacking wheat plants and causing sever reduction in the yield (Slman, 2002). During the last few years, cereal 
aphid became serious insect pests attacking wheat plants in Egypt. Cereal aphids, Rhopalosiphum padi (L.), Schizaphis graminum (Rondani), Sitobion avenae (F). and Diuraphis noxia (Mordvilko) are the most destructive aphid species on wheat. They cause serious yield loss by reducing the number of grains and grain weight per spike of wheat, and indirectly by transmitting viruses (Crespo-Herrera et al., 2013).

The greenbug, Schizaphis graminum, is Palearctic but has been introduced to other parts of the world and is now in North and South America, Europe, Asia, and Africa (Blackman \& Eastop, 2007). It was recorded on wheat plants for the first time by (ElHariry, 1979). Biological control is a major element of integrated pest management plan. Coccinellids are common biological agents for controlling the aphid on cotton and wheat (Khan and Suhail, 2001). The number of lady beetles that develop in a field depends on environmental conditions and the size of the aphid population (Knutson et al., 1997). Thus, both abiotic and biotic factors play an important role in the population buildup of aphid complex and its predator population in the field (Wains et al., 2008). The aim of this study to find out the interaction between predator and environmental factors tounderstand the population dynamics in order to evolve better management practices to reduce the damage caused by aphids.

\section{Materials and Methods}

Studies were carried out on wheat, Triticum aestivum L. var. Shandaweel 1 that planted during the third week of November in both seasons, at Shandaweel Agric. Research Station, Sohag Governorate, through two successive growing seasons of 2015/2016 and 2016/2017. An experimental plot equivalent to $1 / 100$ feddan (i.e. $42 \mathrm{~m}^{2}=$ $6 \mathrm{~m} \times 7 \mathrm{~m}$ ), samples were taken periodically at seven days intervals from the $1^{\text {st }}$ January until the harvest. No chemicals were used at the experimental plots. 10 plants were gathered randomly from three plots in order to direct count for aphid, S. graminum and C. septempunctata. The total number of aphid nymphs, alates and apterous adults of aphids (No. of aphids/tiller) were counted and recorded during the two studied seasons as well as its predator, C. septempunctatain situ on each plant. The individuals of aphids were recorded according to El Heneidy and Adly (2014). Data was analyzed by using average mean population of aphid and its bio-control agents in wheat crop based on monthly recording data.

The data on weather parameter viz. maximum, minimum, mean temperature and mean relative humidity (R.H.\%) were obtained from ; www.accuweather.com and then recorded to correlate with the mean number of aphids in both studied seasons. The mean and simple correlation was calculated in order to find possible relationship of wheat aphid and $C$. septempunctata population with abiotic factors.

\section{Results and Discussion}

The population fluctuation of greenbug, $S$. graminum was studied during two successive seasons of 2015/2016 and 2016/2017. Data in Table (1) indicated the population densities of aphids in wheat plants during 2015/2016-2016/2017 seasons. The nymphs and apterae was first observed in the $4^{\text {th }}$ week of January on 27 January with an average of 8.30, 0.70 and 6.33, 0.33 
aphids/duplicate respectively in both seasons. Its alatae started to appear in $2^{\text {nd }}$ week of February on 10 February (three weeks later) with an average of 0.50 aphids/duplicate in 2015/2016 while in $2016 / 2017$ started to appear in $3^{\text {rd }}$ week of February on 17 February with an average of 0.60 aphids/duplicate.

Thereafter the population fluctuated to reach a maximum of $82.80,11.00$ and 3.90 individuals for nymphs, aptera and alate on 9, 9 and 23 March respectively in season
$2015 / 2016$ and in the next season 2016/2017 the population reached the maximum number of aphids 66.40, 5.10, 4.70 individuals for nymphs, aptera and alate respectively on 16 March . A decline in the aphid population was recorded on 30 March. It is clear that population of alatae in both seasons nearly disappeared from wheat fields a week earlier than other forms. The decline of aphid at the end of month March is of course attributed to the senescence of the.crop.

Table 1. Population density of greenbug (S. graminum) in wheat fields at Shandaweel, Sohag, 2015/2016 and 2016/2017 seasons.

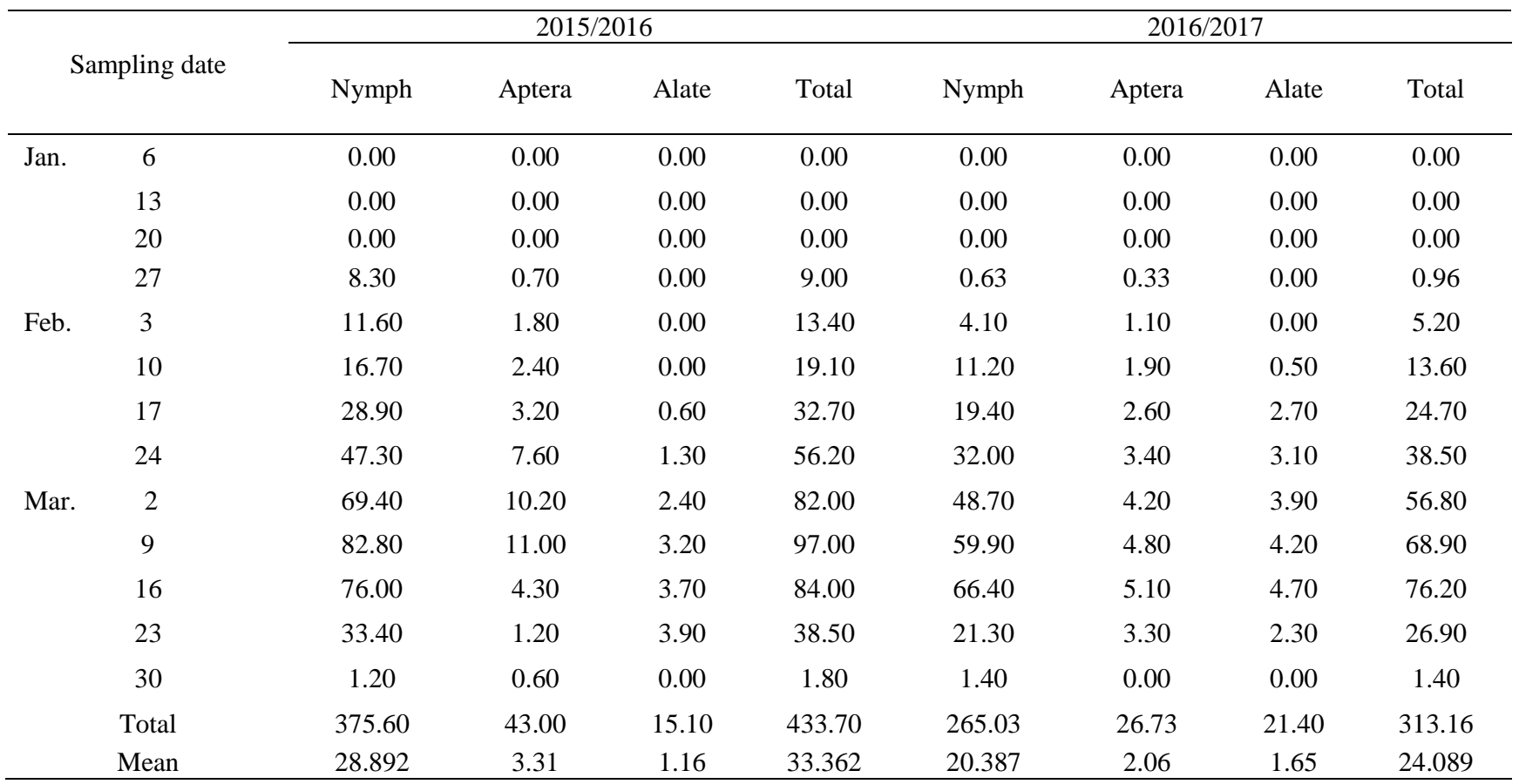


Figure 1, show nymphs were common as compared with other forms in all aphid species. It consisted generally $86.62 \%$ as compared to $9.90 \%$ and $3.48 \%$ of grand total for apterous and alate forms, respectively in season 2015/2016 and in season 2016/2017 almost the same proportions nymphs $84.64 \%, 8.53 \%, 6.83 \%$ for apterous and alate forms, respectively.

The obtained data of both seasons in Table (1 and 2) explaining the population growth of aphids that are similar with El-Heneidy and Abdel-Samad (2001) who said that $S$. graminum starts its occurrence with low population by early January Then, the population declined and approximately vanished from wheat fields during the last week of March .(Aslam et al., 2004; Zeb et al., 2011; Khan et al., 2012) and Abd ElAwal (2005) reported that the first appearance of cereal aphids ( regardless of species ) occurred during the last week of January, The maximum number ( 248.60 individuals / tiller ) occurred on $4^{\text {th }}$ March, the population of cereal aphids declined quickly thereafter and approximately vanished from wheat fields during the last week of March. El-khayat, et al., (2016) found that On wheat, $R$. padi (L.) and $R$. maidis (Fitch) were represented by one peak at the last week of February in 2012/2013 and 2013/2014 seasons (320 \& 285 and 450 \& 266 individuals/sample, respectively), while $S$. graminum (Rond.) recorded one peak on the first week of March in 2012/2013 and 2013/2014 seasons (87 and 79 individuals/sample, respectively). Asid et al., (2015) reported that the aphids population increased from mid of February till the end of March and decreased after that at all locations and also inconsistant with Muhammad etal.,(2013) and Abbas et al., (2014). Results were full agreement with Ajmal et al., (2018) who said that aphid population on wheat crop was on track from $1^{\text {st }}$ week of February to $3^{\text {rd }}$ week of April. The most critical period when the aphid population was observed above the economic threshold level was started from $3^{\text {rd }}$ week of February to $4^{\text {th }}$ week of March which ultimately tend to decrease towards the maturity of crop as temperature started to rise. While results differ from John et al., (2017) who concluded that the maximum aphid infestation was recorded in crops in the 3rd week of February and decline of aphid population was observed in midMarch, the highest aphid population was recorded in mid-Dec sown crop followed by end-Nov and mid-Nov sown crops.

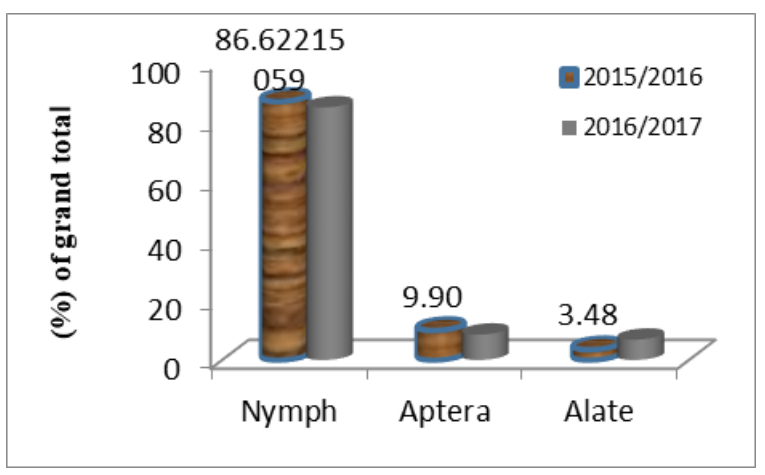

Figure 1. Percentages of grand total of greenbug ( $S$. graminum) in wheat fields at Shandaweel, Sohag, 2015/2016 and 2016/2017 seasons

The Figure 2, showed the winged aphids trapped with sticky trap and explained that there are significant differences between the mean numbers of aphids to different directions. The highest mean number of aphids caught on wheat field was recorded in the eastern direction followed by northern, southern and western sides of the field, respectively. It seems that the eastern direction of the field was sunny and warm so, it is appropriate for receiving the winged aphids and reproduction.

These results were partially consistent with El-Wakeil (2013) who said that wheat aphids was found on the northern direction of the field, while Salem (2012), was in a full agreement with my results when he said that the highest number of cereal aphids was in the eastern side of wheat fields. 


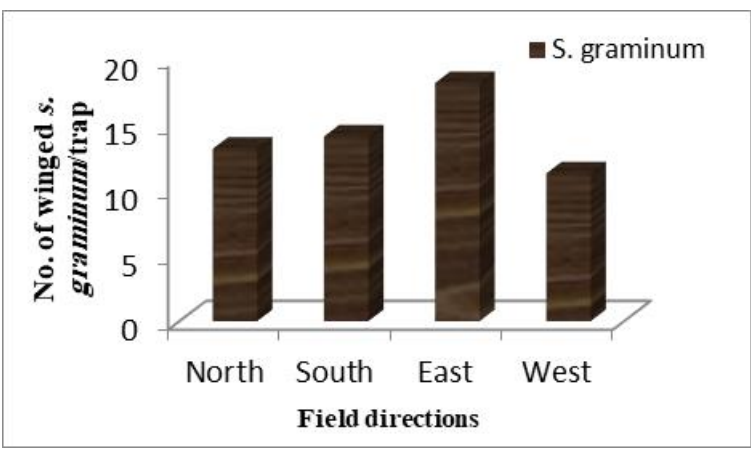

Figure 2. Number of winged $S$. graminum collected from wheat fields in relation to field direction at Shandaweel, Sohag, 2016/2017

Data in Table (2) and Fig. (3) $2015 / 2016$ season showed the first appearance of predator $C$. septempunctata adult was recorded in $4^{\text {th }}$ week of February. The lady bird started appearing; when temperature and mean humidity was $20.29^{\circ} \mathrm{C}$ and 39.57 $\% \mathrm{RH}$, respectively with an average $(0.37$ individuals/tiller). The appearance of lady bird was recorded five weeks after the appearance of aphids. The population of it reached peak in $4^{\text {th }}$ week of March $(7.80$ individuals/tiller) when, temperature and mean humidity was $24.71^{\circ} \mathrm{C}$ and $49.24 \%$
RH, respectively. The aphid started appearing from $4^{\text {th }}$ week of January, however the population was very low ( 0.60 aphid /tiller) at the end of January when minimum and maximum temperature was $7.57^{\circ} \mathrm{C}$ and $22.00^{\circ} \mathrm{C}$ and relative humidity was $48.43 \%$. With the slight increase in maximum temperature from February onwards there was steady increase in aphid population. The aphid population crossed the economic threshold level from the midFebruary and was above the economic injury level in the month of March. The maximum aphid population (97.00 aphids/tiller) was recorded in $2^{\text {nd }}$ week of March. Consequently this population started declining at the end of March and disappeared completely during $1^{\text {st }}$ week of April when maximum temperature was $33.30^{\circ} \mathrm{C}$ and mean relative humidity was $49.57 \% \mathrm{RH}$, possibly owing to the combined action of weather factors, high density of natural enemies, maturity of crop and migration of alate forms.

Table 2. Population density of $S$. graminum and the predator, $C$. septempunctata in wheat fields at Shandaweel, Sohag, 2015/2016 season.

\begin{tabular}{cccccccc}
\hline \multirow{2}{*}{. Sampling date } & \multirow{2}{*}{$\begin{array}{c}\text { Total no. of } \\
\text { aphids/ tiller }\end{array}$} & \multirow{2}{*}{$\begin{array}{c}\text { No. of predator/ } \\
\text { tiller }\end{array}$} & \multicolumn{3}{c}{ Meteorological data } & \multirow{2}{*}{ R.H (\%) } \\
\cline { 5 - 6 } Jan. & 6 & 0.00 & 0.00 & 21.00 & 5.83 & 13.67 & 45.00 \\
& 13 & 0.00 & 0.00 & 24.14 & 8.86 & 16.71 & 44.14 \\
& 20 & 0.60 & 0.00 & 22.00 & 7.57 & 14.86 & 48.43 \\
& 27 & 9.60 & 0.00 & 18.43 & 6.86 & 13.00 & 49.00 \\
Feb. & 3 & 13.40 & 0.00 & 24.42 & 5.14 & 13.71 & 44.71 \\
& 10 & 19.10 & 0.00 & 23.00 & 9.00 & 16.14 & 39.43 \\
& 17 & 32.70 & 0.00 & 29.00 & 9.86 & 19.71 & 42.00 \\
& 24 & 56.20 & 0.37 & 27.00 & 13.14 & 20.29 & 39.57 \\
& 2 & 82.00 & 1.17 & 31.86 & 13.43 & 22.71 & 41.11 \\
& 9 & 97.00 & 1.70 & 29.57 & 12.43 & 21.29 & 43.00 \\
& 16 & 84.00 & 3.90 & 30.14 & 18.29 & 24.29 & 42.27 \\
& 23 & 38.50 & 5.57 & 29.43 & 13.29 & 21.57 & 50.69 \\
& 30 & 1.80 & 7.80 & 31.56 & 17.43 & 24.71 & 49.24 \\
\hline
\end{tabular}



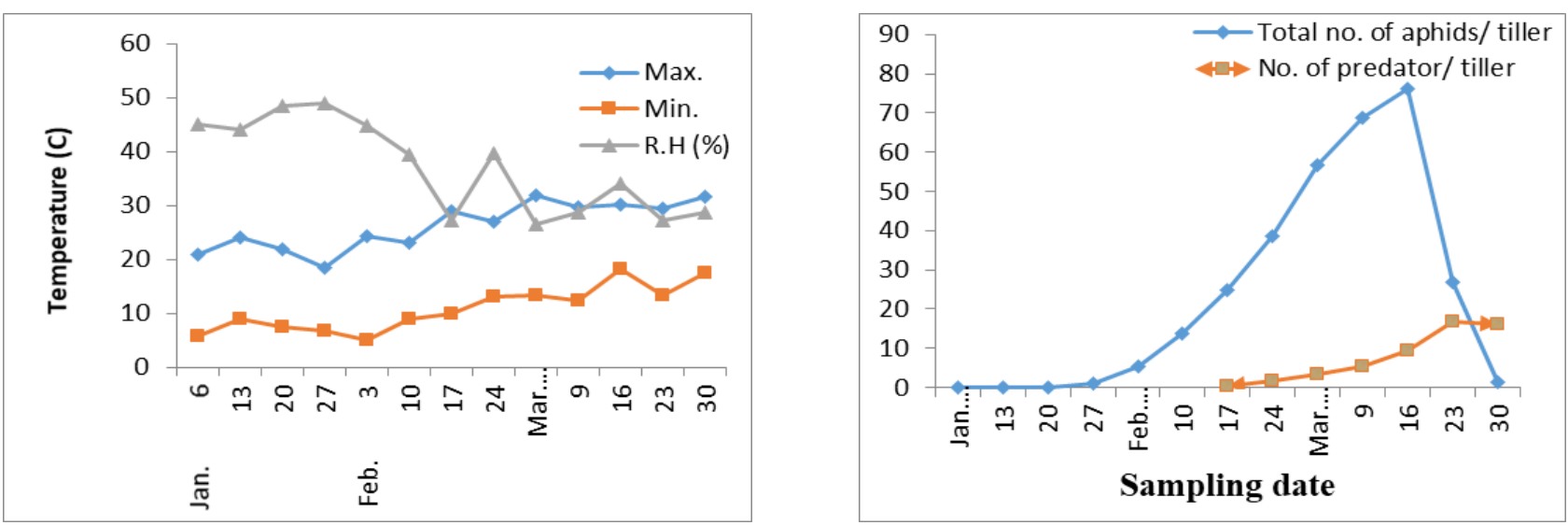

Figure 3. Population density of $S$. graminum and the predator, $C$. septempunctata in wheat fields at Shandaweel, Sohag, 2015/2016 season.

In second season, 2017 Table (3) the predator $C$. septempunctata adult was recorded for the first time in $3^{\text {rd }}$ week of February when temperature and mean humidity was $22.43^{\circ}$ and $51 \%$, respectively with an average ( 0.40 individuals/tiller). The population of it reached peak in $4^{\text {th }}$ week of March (9.06 individuals/tiller) when, temperature and mean humidity was $28^{\circ} \mathrm{C}$ and $45.29 \%$, respectively. The aphid started appearing from $4^{\text {th }}$ week of January, however the population was very low $(0.96$ aphid /tiller) at the end of January when minimum and maximum temperature was $9.57^{\circ} \mathrm{C}$ and $25.86^{\circ} \mathrm{C}$ and relative humidity was $54 \%$. The maximum aphid population (76.20 aphids/tiller) was recorded in $3^{\text {rd }}$ week of March. Consequently, this population started declining at the end of March and disappeared completely during $1^{\text {st }}$ week of April when maximum temperature was $30.30^{\circ} \mathrm{C}$ and mean relative humidity was $47.86 \%$. Soni et al., (2007) reported ladybird beetle, $C$. septempunctata as a potential feeder of wheat aphids that played a predominant role in regulating the aphid population. The population of adult $C$. septempunctata declined steadily from the $1^{\text {st }}$ week of April probably due to scarcity of food (aphids) which caused the migration of adults and decreased the young stages (grubs) of C. septempunctata. Obtained results are in accordance with the findings of
El-Heneidy et al., (2004) who stated that the population density of the predators depended on the densities of aphids and reached its maximum value during February and March, then decreased at the end of the season. Abd EL-Megid et al., (2007) reported that the highest count of the predators was detected during the third and fourth week of March with maximum value of 10 and 13 predators, synchronized with 69 and 37 aphids respectively. The environmental factors like high maximum temperature $\left(34^{\circ} \mathrm{C}\right)$, low humidity $(56 \%)$, more sunshine after the $1^{\text {st }}$ week of April, also played a key role in the decline of adult and grub population. This infers that the abiotic factors regulating the aphid complex population have a similar impact on the predator populations.

Data in Table (4) explained that during the first season, data indicated that a positive correlation was detected between the population density of aphids and (maximum temperature, minimum temperature, the average daily temperature and the predator number) as the calculated ( $\mathrm{r}$ ) values were ( $+0.624, \quad+0.481, \quad+0.524, \quad+0.402)$ respectively. Regarding the effect of relative humidity, the population density of aphids affected insignificantly negative as $r$ value was -0.454. However, the coefficient of determination $\left(\mathrm{R}^{2}\right)$ was 72.74 indication that 
the five mentioned variables were together responsible for $72.74 \%$ of changes in aphid populations in 2016 season. The studied variable can be arranged in a descending order as follows: Average daily temperature, maximum temperature, average relative humidity, minimum temperature and the predator numbers, where their efficiency were $23.70, \quad 20.37, \quad 1.90, \quad 1.79, \quad 1.32$ respectively.

Table 3. Population density of $S$. graminum and the predator, $C$. septempunctatin wheat fields at Shandaweel, Sohag,2016/2017 season.

\begin{tabular}{lccccccc}
\hline \multirow{2}{*}{ Sampling date } & \multirow{2}{*}{$\begin{array}{c}\text { Total no. of } \\
\text { aphids/ tiller }\end{array}$} & $\begin{array}{c}\text { No. of predator/ } \\
\text { tiller }\end{array}$ & \multicolumn{3}{c}{ Meteorological data } & \multirow{2}{*}{ R.H (\%) } \\
\cline { 1 - 3 } Jan. & 4 & 0.00 & 0.00 & 20.57 & 6.00 & 14.00 & 53.43 \\
& 11 & 0.00 & 0.00 & 24.14 & 4.57 & 12.57 & 51.29 \\
& 18 & 0.00 & 0.00 & 24.29 & 6.86 & 15.71 & 49.00 \\
Feb. & 25 & 0.96 & 0.00 & 25.86 & 9.57 & 17.86 & 54.00 \\
& 1 & 5.20 & 0.00 & 22.57 & 7.29 & 15.14 & 42.14 \\
& 15 & 13.60 & 0.00 & 23.86 & 8.00 & 16.29 & 45.14 \\
Mar. & 24.70 & 0.40 & 22.43 & 8.29 & 15.71 & 51.00 \\
& 15 & 38.50 & 1.52 & 21.29 & 6.43 & 14.14 & 48.86 \\
& 1 & 56.80 & 2.84 & 27.57 & 10.29 & 19.14 & 50.29 \\
& 8 & 68.90 & 4.37 & 28.29 & 10.57 & 19.71 & 52.86 \\
& 15 & 76.20 & 6.01 & 28.00 & 11.57 & 20.00 & 49.14 \\
& 22 & 26.90 & 7.80 & 26.86 & 12.43 & 20.00 & 47.43 \\
& 29 & 1.40 & 9.06 & 29.29 & 13.86 & 21.71 & 45.29 \\
\hline
\end{tabular}

Table 4. Multiple-regression analysis between the total number of S. graminum, predator and abiotic factors during 2015/2016season.

\begin{tabular}{cccccc}
\hline Variable removed & $\mathrm{R}$ & $\mathrm{R}$ & $\mathrm{R}^{2} * 100$ & Decrease in $\mathrm{R}^{2 * 100}$ & Efficiency \\
\hline Non & - & 0.831 & 72.74 & - & - \\
Max. temp. & $0.6524 *$ & 0.747 & 51.80 & 20.94 & 20.371 \\
Mini. Temp. & 0.4810 & 0.862 & 70.90 & 1.84 & 1.7916 \\
Avg. daily temp. & 0.5420 & 0.640 & 48.37 & 24.37 & 23.703 \\
Avg. R.H. (\%) & -0.4540 & 0.814 & 74.70 & 1.96 & 1.9004 \\
Predator no. & 0.4012 & 0.844 & 71.38 & 1.36 & 1.3202 \\
\hline \multicolumn{5}{r}{ r = Simple correlation coefficient. } \\
\multicolumn{7}{r}{ R = Multiregression coefficient. } & $\mathrm{R}^{2}=$ Coefficient of determination \\
\end{tabular}


In the second season, data in Table 5, the results took the same trend as in the first season, the population density of aphids correlated insignificantly positive with maximum, minimum temperature, the average daily temperature and the predator number, and insignificantly negative with relative humidity, where the values were ( $+0.6587,+0.4720,+0.3640,+0.4580$, $0.3910)$ respectively. And the coefficient of determination $\left(\mathrm{R}^{2}\right)$ was 50.27 that is mean the five mentioned variables were together responsible for $50.27 \%$ of the changes in aphid populations during 2017 season. Most of the changes in aphids' populations however were due to the predator numbers (39.05) and maximum temperature (33.36).

Overall correlation study of wheat aphid populations showed good positive correlation with the maximum temperature, the average daily temperature, minimum temperature and the predator number, while the aphid populations showed negative correlation with relative humidity in both seasons. Temperature in 2015/2016 season and predator number in 2016/2017 season played an important role in regulating aphids' populations.
From the previous results of the effect of climatic factors on the population density of aphid are partially agree with that obtained by several authors on different crops. Similar to our findings Abd El-Awal, (2005) reported that minimum and maximum temperatures had a significant and positive role in causing fluctuation in the aphid population, however relative humidity revealed a negative and significant correlation with aphid population Wains et al., (2008). Saleem et al., (2009) mentioned that major activities of aphid species were correlated with the rising temperature in the month of February, but as the crop mature, fewer aphids were found in wheat plants. Wains et al., (2010) reported that aphids' density was positively associated with maximum and minimum temperature, while it showed negative correlation with relative humidity. Hussein et al., ( 2015) reported that during the first season, data indicated that a positive correlation was detected between the population density of aphids and both of maximum and minimum temperature and the effect of relative humidity, it is clear that the population density of aphids affected insignificantly negative.

Table 5. Multiple-regression analysis between the total number of S. graminum, predator and abiotic factors during 2016/2017season.

\begin{tabular}{lccccc}
\hline Variable removed & $\mathrm{R}$ & $\mathrm{R}$ & $\mathrm{R}^{2} * 100$ & Decrease in $\mathrm{R}^{2} * 100$ & Efficiency \\
\hline Non & - & 0.696 & 50.27 & - & - \\
Max. temp. & 0.5687 & 0.7654 & 58.48 & 8.21 & 33.362 \\
Mini. Temp. & 0.4720 & 0.6115 & 50.64 & 0.37 & 1.9487 \\
Avg. daily temp. & 0.3640 & 0.6891 & 48.07 & 2.20 & 11.510 \\
Avg. R.H. (\%) & -0.3910 & 0.7078 & 52.34 & 2.07 & 10.740 \\
Predator no. & 0.4580 & 0.7642 & 57.67 & 7.40 & 39.048 \\
\hline
\end{tabular}

$\mathrm{r}=$ Simple correlation coefficient. $\quad \mathrm{R}=$ Multiregression coefficient. $\mathrm{R}^{2}=$ Coefficient of determination 

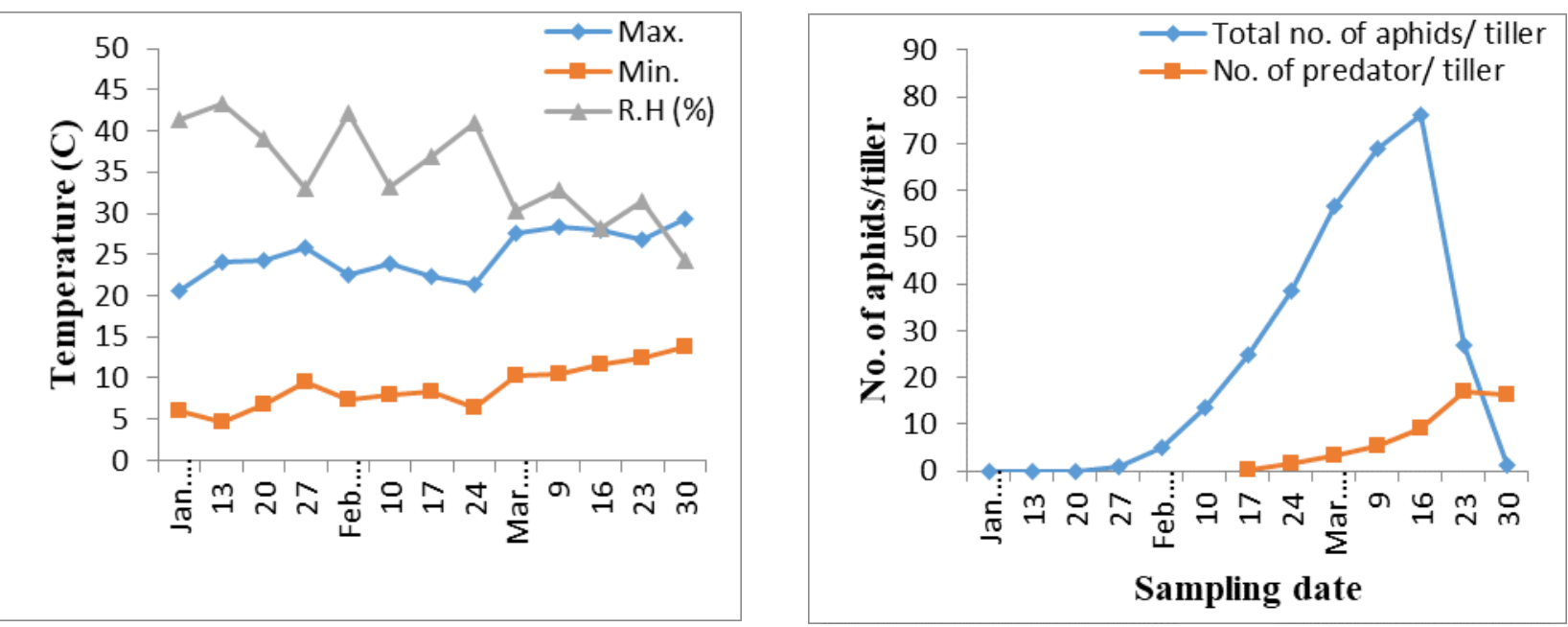

Figure 4. Population density of $S$. graminum and the predator, C. septempunctata in wheat fields at Shandaweel, Sohag, 2016/2017 season.

In the second season, the results took the same trend as in the first season, the population density of aphids correlated insignificantly positive with maximum \& minimum temperature and insignificantly negative with maximum and minimum relative humidity. These obtained results completely different with Aml et al., (2019) who found that the correlation coefficient between $S$. graminum infesting barely plants and maximum temperature was negative and insignificant $(\mathrm{r} 1=-0.324$ and -0.422$)$ in the two seasons, respectively. The correlation coefficient between $S$. graminum and minimum temperature was negative and insignificant ( $\mathrm{r} 2=-0.135$ and -0.365$)$ in the two seasons, respectively. While, relative humidity was negatively insignificant and positively insignificant $(\mathrm{r} 3=-0.013$ and 0.003 ) in the two seasons, respectively).

\section{Conclusion}

Generally, it could be concluded $C$. septempunctata should be considered a promising candidate for utilization in biological control of $S$. graminum and the abiotic factors were the most important for management this pest under field conditions.

\section{Conflict of interest}

The authors hereby declare that no competing and conflict of interests exist.

\section{References}

Abbas, Q., Ahmad, I., Shahid, M.A., Akhtar, M.F., Hussain, M., Akram, M. and Raza, A. (2014) ' Role of climatic factors on population fluctuation of aphids(Brevicoryne brassicae, Myzus persicae and Lipaphis erysimi) on canola (Brassica napus) in Punjab, Pakistan ', Pakistan J. Nutr., 13, pp. 705-709.

Abd El-Awal, M. W. (2005) 'Ecological studies on cereal aphids and their control in Sohag governorate ', Ph. D. Thesis, Fac. of Agric. Assuit Univ., 171pp.

Abd El-Megid Jasmin E.; El-Maghraby M. A.; Hammad K. A. A. and El-Baz I. M. (2007) 'Cereal aphids on wheat and their associated aphidophagous insect predators', Zagazig J. Agric. Res., 34 (3), pp. 559-577. 
Ajmal M. S., Iqbal, J., Qayyum, M. A., Saleem, M. A., Tayyab, M., and Sajjad, M. (2018) 'Preferential influence of wheat varieties (Triticum aestivum L.) on population build-up of aphid (Homoptera: Aphididae) and its natural enemies '. 6(1), pp. 609-612

Aml Z. N. Al - Habshy; S. A. M. Amer and M.S. Hashem (2019) 'Population Fluctuations of Aphid and Leafhopper Insects Infesting Barely Plants and Some Predators', Egy. J. of Plant Protection and Pathology, Mansoura Univ., 10 (9), pp. 451-457.

Asid Ali and Hirad Ali (2015) 'Population Dynamics of Cereal Aphids in Wheat Crop at District Swabi ', Int. J. of Agric. and Enviro Res. 1(1), pp.25-31.

Aslam, M., Razaq, M., Ahmad, F., Faheem, M. and Akhter, W. (2004) 'Population of aphid (Schizaphis graminum R.) on different varieties/lines of wheat (Triticum aestivum L.)', Int. J. agric. Biol., 6: 974-977.

Blackman, R.L., Eastop, V.F. (2007) 'Taxonomic issue. In: van Emden, H.F., Harrington, R. (ed.), Aphids as crop pests', CABI, Wallingford, London, United Kingdom, pp. 1-29.

Crespo-Herrera, L.A., Smith, C.M., Ravi, Singh P., Hman, A. (2013) 'Resistance to multiple cereal aphids in wheat-alien substitution and translocation lines. Arthropod-Plant Interactions', 7, pp. 535-545.

El-Gizawy N.K.B. (2009) 'Effect of planting date and fertilizer application on yield of wheat under no till system', World J. of Agric. Sci., 5, pp.777- 783.

El-Hariry, M. A. (1979) 'Biological and ecological studies on aphids attacking corn and wheat in Egypt', M. Sc. Thesis, Fac. of Agric., Ain Shams Univ., Egypt., 213 pp.
El-Heneidy, A. H., and Adly, D. (2014) 'Cereal aphids and their biological control agents in Egypt', Egy. J. of Biol. Pest Cont., 22, pp. 227-244.

El-Heneidy, A. H. and Abdel-Samad S.S. (2001) 'Tritrophic interaction among Egyptian wheat plant, cereal aphids and natural enemies', Egy. J. Biol. Pest Cont., 11(2), pp. 119-125.

El-Heneidy, A.H.; G. N. Rezk; AbdelMegeed M. A. and Salwa, AbdelSamad S. M. (2004) 'Comparative study of cereal aphids' species and their associated predators and parasitoids in two different wheat regions in Egypt', Egy. J. Biol. Pest Cont., 14 (1), pp. 217224 (Proceeding of $1^{\text {st }}$ Arab Conf. for Applied Biol. Pest Cont., Cairo, Egypt, 5-7.

El-Khayat, E. F.; Aziza M. EL-Gantiry; Rasha A. El-Hosserey and S. A. Amer (2016) 'Ecological studies on Aphid Species Infesting Main Cereal Crops', Annals of Agric. Sci., Moshtohor, 54(1), pp. $129-138$.

El-Wakeil N., and Volkmar C. (2013) 'Monitoring of wheat insects and their natural enemies using sticky traps in wheat', Arch Phytopathol Plant Protect. 46(13-16), pp. 1523-1532.

John, F., Saeed, N. A., Nadeem, S., and Hamed, M. (2017) 'Integration of planting time and insecticide to manage aphid infestations in wheat for better crop productivity. Pakistan J. Zool, 49(4), pp. 1343-1351.

Khan, A.M., Khan, A.A., Afzal, M. and Iqbal, M.S. (2012) 'Wheat crop yield losses caused by aphid infestation', Biofertil. Biopestic., 3, pp. $1-7$.

Khan, H.A. and A. Suhail (2001) 'Feeding efficacy, circadian rhythums and oviposition of lady bird beetle (Coccinellidae: Coleoptera) under 
controlled conditions', Int. J. Agric. and Biol., 3, pp. 384-386.

Knutson A., Boring B.P., and Michels G.J. (1997) 'Biological control of aphid population and their natural enemies', Texas Agri. Exp. Stat. Texas A and M Univ.

Milad, S. I., El-Banna M. N., El-Sheikh M. H. and Ebaid M. E. (2013) 'Effect of genotypes and medium protocols on callus formation and plant regeneration from mature embryos of Egyptian wheat (Triticum aestivum L.) varieties. ', J. Adv. Agric. Res., 18(4), pp. 874889.

Muhammad, W., Nasir, M., Abbas, S.K., Irshad, M., Abbas, M.W., Nawaz, A. and Rehman, A. (2013) 'Resistance pattern against aphid (Diuraphis noxia) in different wheat varieties/lines at district Layyah ', Acad. J. Ent., 6, pp. 116-120.

Hussein S. H. A., Hanafy A. R. I. and El Sappagh I. A. (2015) 'Impact of planting dates and some weather factors on population fluctuation and occurrence percentage of aphids and thrips on wheat crop in Egypt', J. of Phytopathology and Pest Management 2(3), pp. 18- 31.

Saleem S., Ullah F., Ashfaque M. (2009) 'Population dynamics and natural enemies of aphids on winter wheat in Peshawar', Pakistan J. of Zoology, 41, pp. 505-513.

Salem A. A. A., and Mahmoud H. H. (2012) 'Population fluctuations of cereal aphids and their associated Hymenopterous parasitoids in wheat fields', Minia J. Agric. Res. Develop. 32(2), pp. 279-296.

Slman F.A.A. (2002) 'Influence of some agricultural practices on the infestation of wheat crop by cereal aphids in Upper
Egypt', Assiut J. of Agric. Sci. 33, pp. 112.

Soni R., Deol G.S. and Brar K.S. (2007) 'Feeding potential of Coccinella septempunctata Linné. (Coleoptera: Coccinellidae) on wheat aphid complex under cage conditions', J. Insect Sci., 20, pp.118- 119.

Wains M.S., Ali M.A., Anwar M.H.J, Zulkiffal M. and Sabir W. (2010) 'Aphid dynamics in relation to meteorological factors and various management practices in bread wheat ', J. of P. P. Res., 50, pp.385-392.

Wains, M. S., Latif, M., and Hussain, M. (2008) 'Aphid dynamics in wheat as affected by weather and crop planting time', Pakistan J. of Agric. Res. 46, pp. 361-366.

Zeb Q., Badshah H., Ali H., Shah, R.A. and Rehman M. (2011) 'Population of aphids on different varieties/lines of wheat and their effect on yield and thousands grain weight', Sarhad $J$. Agric., 27, pp.443-4 